Balancing food risks and food benefits: The coverage of probiotics in the UK national press

Brigitte Nerlich and Nelya Koteyko

\title{
Abstract
}

The 1980 s and 1990 s were marked by a series of food crises, environmental disasters and the rise of so-called 'superbugs'. The resulting change in attitudes to science, society and food has been studied by many social scientists, from Ulrich Beck (1986) onwards. The late 1990s and early years of this new millennium have been marked by the rise of consumer interest in organic and natural foods but also in probiotics or friendly bacteria which, as supplements or added to yoghurts, promise to help fight various effects of 'modernity', from stress to superbugs. Using thematic analysis and corpus linguistic tools, this article charts the rise of probiotics from 1985 to 2006 and asks: How did this rise in popularity come about? How did science and the media contribute to it? And: How were these bacteria enlisted as agents of attitudinal change? Analysing the construction of the food benefits in the context of a heightened state of anxiety about food risk might shed light on aspects of 'risk society' that have so far been overlooked.

Keywords: food risks, food benefits, probiotics, media, risk society, medicalisation

Wordcount: 7,031 
Balancing food risks and food benefits: The popularisation of probiotics in the UK national press

\author{
Look in your yoghurt \\ You'll find them there \\ Healthy bugs are everywhere \\ Rid your chooks of all that's toxic \\ A boon to mankind, the probiotic. \\ (<http://www.abc.net.au/rn/science/ss/st \\ ories/s1076172.htm>)
}

\title{
Introduction
}

Following a series of food scares and food scandals (see Fitzgerald and Campbell, 2001), the late 1980 s and early 1990 s were a time of heightened food anxiety and food insecurity: the first case of BSE (Bovine Spongiform Encephalopathy) or 'mad cow disease' in cattle in 1986 and outbreaks of salmonella in eggs in 1989 were followed in rapid succession by outbreaks of Campylobacter gastroenteritis, Listeria, E. Coli and even botulism, after a batch of hazelnut yoghurt infected 27 people (see HPA, 2006; Iliffe, 1990). The 1990s were a time when two food scares dominated the media: first there was BSE (again) after it was found that it can be transmitted from cattle to humans via infected meat and can cause variant Creutzfeldt-Jakob disease, a form of TSE or Transmissible Spongiform Encephalopathy; second there was genetically modified food, which generated a lot of controversy and anxiety from about 1998 onwards, especially in Europe (see Knowles, et al., 2007).

At the same time, between 1985 and 1995, another issue crept into the media spotlight, namely that of killer germs and superbugs, from AIDS to Ebola and from MRSA (Methicillin Resistant Staphylococcus Aureus) to Clostridium difficile (Washer and Joffe, 2006). Killer viruses and killer bacteria were thought 
to be on the march (Nerlich and Koteyko, in press) and people feared that if they didn't get you through your food, they got you through a cut in you skin (Raman, in press).

During the same period, between the mid-1980s and mid-1990s, a new theory of risk and modernity began to spread, prompted by various environmental and industrial disasters. In 1986 Beck published his controversial book Risikogesellschaft in Germany and the English translation, Risk Society: Towards a New Modernity, appeared in 1992 (Beck, 1986, 1992). According to Beck, risk in modern society can be defined as a systematic way of dealing with hazards and insecurities induced and introduced by modernization itself (Beck 1992: 21). Beck did not study food risks extensively in his $1986 / 1992$ book, only referring briefly to the risk of pollution (p. 25-26) and pointing out that " $[t]$ he lists of toxins and pollutants in foodstuffs and articles of daily use grow longer and longer" (p. 55). Ironically, as we have seen, after 1986 food scares began to dominate the media, from Chernobyl to GM. However, Beck points out that "it is not clear whether it is the risks that have intensified, or our view of them. Both sides converge, condition each other, strengthen each other, and because risks are risks in knowledge, perceptions of risks and risks are not different things, but one and the same." (ibid.) This echoes views expressed by Mary Douglas and Aaron Wildavsky that "[t]he perception of risk is a social process" (Douglas and Wildavsky, 1982: 6). The 1980s and 1990s therefore saw the emergence of a new movement in risk research, the so-called 'socio-cultural approach to risk' ( Tulloch and Lupton, 2003). Our article stands in this tradition but gives it a more linguistic twist.

Beck also briefly discussed another issue relating to food and risk, namely the invisibility of many toxins and pathogens (Beck, 1992: 55). An expert in food safety, Eivind Jacobson, points out that this characterises not only modern food risks but has always been so. 
What's new, however, is the fact that we eat more food produced and processed by actors unknown to us, and, as we are eating more and more readymade meals, the ingredients, their sources and mixture, are more and more unknown to us as consumers. New is also a realization that some of the stuff we eat and drink has long-term effects hardly thought about in earlier periods. Moreover, these factors are stressed by the industrial nature of food production and the application of science in order to improve these processes and the products coming out of them.

Somehow the role of science and the idea of modernity seem to disturb us when it comes to food: A lot of us seem to have a nostalgic notion of what food is and should be about. The 'food-pills' of the science-fiction stories of the 1950-60ies never really caught on by us; they more looked like threats than promises [...]. (Jacobson, 2004: 2)

However, since 2003/04, when this text was written, new food products have come on the market that resemble these 'food-pills' but that are associated more with hopes and promises rather than fears and threats, namely probiotic supplements, drinks and yoghurts.

Analysing the social construction of the 'benefits' of friendly bacteria, which are as invisible and as unknown as the food risks discussed by Beck and others, might therefore shed light on aspects of 'risk society' that have so far been overlooked. They too need to be 'constructed' by the public as they are not directly 'perceptible' through the naked eye. As in the case of some risks, these are 'virtual' benefits, and, as with some types of food risks, the science of these food benefits is, as yet, inconclusive. As John Adams said with reference to risk and we have replaced the word risk with benefit in his quote: 
[...] where the science is inconclusive we are thrown back on judgement. We are in the realm of virtual benefit. These benefits are culturally constructed - when the science is inconclusive people are liberated to argue from, and act upon, pre-established beliefs, convictions, prejudices and superstitions. Such benefits may or may not be real but they have real consequences. In the presence of virtual benefits what we believe depends on whom we believe, and whom we believe depends on whom we trust. (Adams, 2005)

The food scares of the 1980s and 1990s, and the subsequent loss of trust in scientists and policy makers, provoked profound changes in shopping and eating habits. Organic and pesticide free food, for example, were seen as a safe haven for the ambivalent and frightened consumer and are now experiencing a consumer boom (Soil Association, 2007). At the beginning of the 1990s, a new product became more widely available, also associated with hopes and promises rather than fears and anxieties, namely, probiotics, more generally known as 'friendly bacteria' or 'good bacteria', as opposed to bad bacteria that cause infection and illness.

They were first used in animals after the widespread use of antibiotics in animal husbandry came under suspicion. More recently they have become a mainstream sector of the dairy industry and have been heavily promoted for human consumption. They are regarded as a type of 'novel' or 'functional food' (Wright et al., 2003) and have an uncertain status between food and drugs and between 'natural' and 'engineered' foods. Despite the fact that benefits for healthy people are uncertain and messages to consumers conflicting, probiotic drinks have become one of the fastest growing sectors in the dairy market (Redruello, 2004). How did this rise in popularity come about? How did science 
and the media contribute to it? How were these bacteria portrayed at a time when the fear of toxins and germs began to taint eating and living in a modern world?

After a short section devoted to outlining the methods used in our analysis, we will go on to examine how probiotics were discussed in the UK national press during a first 'probiotic decade', that is, between 1985 (when the term 'probiotic' first appeared in the UK national press) and 1995 (when they began to become more mainstream), in order to reveal which themes, hopes and fears were addressed, and which developments in science set the media agenda. This will be followed by a short overview of the themes and issues covered by the UK national press during the second probiotic decade, that is, between 1996 and 2006. This will allow us to chart the gradual recruitment of probiotics as 'agents' of change in the public perceptions of health and illness, of the body and the environment and, perhaps, of microbial life itself. As Dupré has recently pointed out:

The friendly germ may sound a rather implausible idea. [...]

Anthropologists have convinced us that being dirt is not an intrinsic property of things, but only a reflection of things in the wrong place (mud on the carpet rather than in the field, and so on). But germs are close to being essentially dirt: we don't want them anywhere. The only good one is a dead one. Against all this, one may now encounter the concept of a friendly germ in the public domain, as something, for example, that can be found in the right kind of yogurt. And banal though this reference may be, it points us in the direction of a much more appropriate attitude to microscopic life [...]. (Dupré, 2007.) 
In this quote Dupré indirectly refers to Mary Douglas's seminal anthropological study of 'purity' and 'danger' (Douglas, 1966). Drawing on Lord Chesterfield's classic definition of dirt as matter out of place, Douglas argues that "[w]here there is dirt there is system. Dirt is the by-product of a systematic ordering and classification of matter, in so far as ordering involves rejecting inappropriate elements" (p. 36). She also points out that "ideas about separating, purifying, demarcating and punishing transgressions have as their main function to impose a system on an inherently untidy experience" (p. 4). Similar efforts at imposing a new system are made when separating good from bad bacteria and distinguishing between what poses risks to animal and human health and what might be of benefit.

\section{Methods and conceptual framework}

After the BSE scandal and the GM food debate social scientists and scholars in science and technology studies began to examine in great detail the public understanding of issues relating to food, science and risk (to cite just a few: Gaskell et al., 1998; Gaskell et al., 2004; Hunt and Frewer, 2001; Marris et al., 2001). The public perception of 'food risks' mediated by the news media attracted a great deal of scholarly attention (e.g. Shaw 1999, 2000), but only little research has been carried out so far into the public and media framing of 'food benefits' (but see Marks and Kalaitzandonakes, 2001; Frewer et al., 1997); and while some articles have studied the media framing of the risks posed by 'unfriendly bacteria' (Washer and Joffe, 2006; Crawford et al., in press), social scientists have not yet examined in any detail the framing of the benefits derived from 'friendly bacteria' (but see e.g. Bech-Larsen and Scholderer, 2006 for a view from the industry). In this article we will adapt methods used in studying media framing of risks and disease (Wallis and Nerlich, 2005; Nerlich and Koteyko, in press) to studying media framing of benefits and health. 
Using both qualitative and quantitative methods, we will analyse two bodies or 'corpora' of texts from the UK national press, one quite small one and one larger one. The smaller corpus consists of 16 articles published in UK national newspapers during a first 'probiotic decade' (1985-1995). The second corpus contains 837 articles published between 1996 and 2006 in the UK national press (see figure 1).

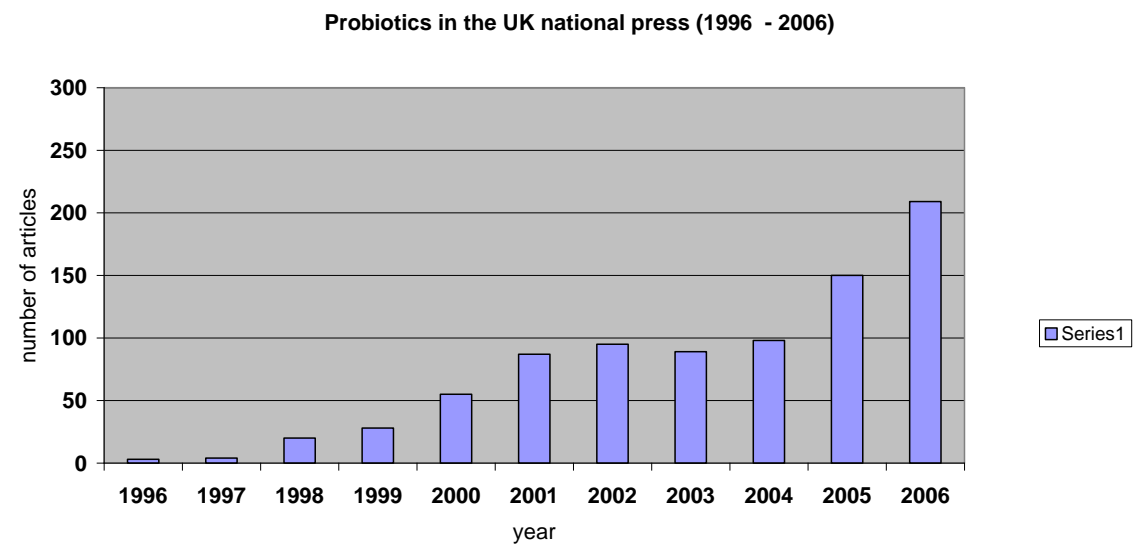

Figure 1: Probiotics in UK national press, 1996-2006

All articles were accessed via Lexis Nexis Professional, using 'probiotic' as a keyword. (This provides online access to newspaper articles, but does not provide access to the original page numbers). The first small corpus will be used to trace emergent themes and framing devices using in-depth qualitative thematic and frame analysis. The second corpus will be analysed using corpus linguistic tools such as collocational profiles and concordances generated with the help of WordSmith (Scott, 1999) in order to determine changes in reporting trends and continuity or discontinuity of themes. A collocational profile is helpful for studying 
the lexical surroundings of a word as it presents a list of words which co-occur with a chosen search term, normally within a span of 5 words to the right and 5 words to the left (Sinclair, 1991; Scott, 1999). A set of concordance lines presents instances of a word or phrase usually in the centre, with words that come before and after it to the left and right which provide quick access to a number of contexts where a selected word is used. These corpus linguistic tools can complement discourse and frame analysis with a quantitative dimension which enables researchers to evaluate the generality of the highly particular insights gained from qualitative analysis (Sinclair, 1991; Stubbs, 1996, 2006). The qualitative analysis is based on 'frame analysis', especially a type of frame analysis promoted by Iyengar (1987). According to Iyengar, the frames for a given story are seldom conscientiously chosen but represent instead the effort of the journalist or sponsor to convey a story in a direct and meaningful way. As such, news frames are frequently drawn from, and reflective of, shared cultural narratives and myths and resonate with the larger social themes to which journalists tend to be acutely sensitive (Iyengar, 1987). In another study, published in 1991, Iyengar makes a distinction between episodic and thematic media framing, especially with reference to television news. "Episodic framing depicts concrete events that illustrate issues, while thematic framing presents collective or general evidence." (Iyengar, 1991: 14) Thematic framing puts issues or events into some general context, while episodic framing focuses on specific events and particular cases. These concepts will be used to trace changes in news coverage over two decades, between 1985 and 2006. Our choice to study the material in two 'decade' chunks was guided by pragmatic reasons so as to make the material manageable for analysis, but also by reasons intrinsic to the material analysed. The first decade $(1985$ - 1995) is characterized by a small and irregular coverage of probiotics, whereas during the second decade (1996-2006) there was a marked and steady increase in the number of articles mentioning probiotics until the coverage peaked in 2006 (see Figure 1). 


\section{Early coverage of probiotics, 1985-1995: Emerging themes}

In 1908, the Russian Nobel Prize Laureate Ellie Metchnikoff (1908) hypothesized that a high concentration of lactobacilli in intestinal flora was important for health and longevity in humans. This concept was popularised by Loudon Douglas in his 1911 bestseller The Bacillus of Long Life (Douglas, 1911) (Knothe, 1995).

Scherzenmeir and de Vrese (2001) point out that probiotics in the modern sense have been studied since about 1965 when Lilly and Stillwell contrasted them with antibiotics. They claim that, in 1974, Parker was the fist to use the term in the sense that is used today. He defined probiotics as 'organisms and substances which contribute to intestinal microbial balance' (Scherzenmeir and de Vrese, 2001: 361S) - a word and a theme that would dominate the popular coverage of probiotics up to the present.

The theme of the beneficial effects of probiotics was first explored for animals, then humans. In animals the '[f]eeding of live microorganisms has led [...] to a reduction in the colonisation of chickens with Salmonella enteritidis phage type 4' (Millar et al., 2003) - one of the major food risks that had plagued the 1980s. Other benefits are still being explored.

Our story of probiotics in the UK national press begins in 1985 with an article for the Guardian by Professor Roy Fuller who was working on probiotics at the University of Reading at the time and is now an Intestinal Microecology Consultant ${ }^{1}$. In this article Fuller provides the following definition of 'probiotic' that is, four years before its official publication in an academic journal (Fuller, 1989a - referenced in Scherzenmeir and de Vrese, for example): 
The word 'probiotic' was coined to describe these food supplements which contain living bacteria. It is derived from the Greek words meaning 'for life' in contrast to the word 'antibiotic' which means 'against life.'

Paradoxically the probiotic effect of an organism may be dependent on its antibiotic activity. Thus the ability of probiotic preparations to stimulate the growth of farm animals may be a result of their killing off the microorganisms which depress the growth of these animals. (Fuller, 1985)

This definition opens the first probiotic media decade when major themes of debate emerged. This decade was framed by two rather evocative headlines. Fuller's 1985 article was entitled: 'The message in the tub of natural yoghurt'. This message in a tub would float well until it reached our present day shores. At the end of this first decade, in 1995, an article by Mitchell for The Times was entitled 'Where extra health is stirred into the mix', which prefigures claims about 'added goodness' that were to be made more and more on tubs and bottles in the years to follow (Koteyko and Nerlich, 2007). The 1985 article by Fuller ends on a still relatively cautious note:

The acceptance of these bacterial supplements by animals will present no problems but could we be persuaded to eat them? [...] what we are likely to see in the near future is the increased use of live supplements of bacteria originating from the healthy intestinal tract. The reaction of the human consumer to such products will be interesting to see but if the health benefits can be substantiated the acceptance, as it has been with bran, will be assured. (Fuller, 1985) 
Ten years later the question about whether humans could be persuaded to eat bacteria and regard this as a benefit to their health and well-being is no longer posed, as the beginning of the 1995 article by Mitchell demonstrates:

Functional foods with built-in benefits are the buzz now [...]. A new marketing bandwagon is about to hit shoppers. After a period when so much we ate seemed potentially harmful and when products that were fatfree, sugar-free and additive-free were all the rage, marketers have hit on a grand scheme. Instead of taking out nasties such as fat and sugar, they have started adding special health goodies. (Mitchell, 1995)

The message about 'extra' health being added to or stirred into the yoghurt and about food with 'built-in' benefits was about to be promoted loud and clear over the following decade (Koteyko and Nerlich, 2007). Consumers who had been urged to abstain from certain nasty food ingredients added to food, such as sugar or salt were now being encouraged to enjoy the 'health goodies' added to food, such as probiotics and cholesterol reducing plant extracts, fibre and calcium, omega 3 and many more. The dichotomy between good and bad would become well established. Let us now take a closer look at the decade spanning the time between 1985 and 1995 when this run-in between good and bad bacteria first emerged.

As already indicated, salmonella infections were a serious concern to farmers, egg-producers and consumers in the mid-1980s. In response, the Lion Quality Code of Practice was launched in 1989 with the objective of producing safe, Salmonella-free eggs for human consumption. Another growing concern was the overuse of antimicrobials in animal husbandry (both for therapeutic reasons and as growth promoters) and the rise in antimicrobial resistance. 
In 1969 the UK Swann Report had highlighted the dangers of antimicrobials in the food chain and, beginning with Sweden in 1986, the European Union gradually banned all growth-promoting antibiotics (Casewell et al., 2003). This issue became even more important with the emergence of multiresistant bacteria, such as MRSA and VRSA (Vancomycin resistant staphylococcus aureus) in humans (Teale, 2002) and, more recently, in animals (see Waller, 2005). As a result, scientists began to explore alternatives to the use of antibiotics in animal husbandry (and the same is happening now for humans). As Fuller pointed out in 1985 , both animals and humans, especially young chicks and premature babies, reared or treated in incubators and separated from their mothers, may benefit from probiotic treatments. Over the two decades studied here the University of Reading has been at the forefront of probiotic research, most recently with research signalling the importance of probiotics for the elderly (BBC News, 2006). In 1985 Fuller wrote:

The replacing of antibacterial agents with probiotic supplements would remove the danger of antibiotic resistance. They are also cheaper to produce and, since they are natural inhabitants of the gut, are unlikely to have any adverse side effects. [...] There is now increasing evidence for believing that the intestinal bacteria have a protective role and that their transfer from mother to offspring is important.

Two themes should be highlighted here: bacteria as 'natural inhabitants' that have a 'protective role' and the issue of obsessive hygiene. On the one hand, too much cleanliness was regarded as a factor in the rise of children's allergies; on the other hand too little cleanliness began to be seen as a factor in the rise of socalled 'superbugs', such as MRSA and Clostridium difficile, in hospitals (where cleanliness came to be promoted as a panacea over and above the reduction in 
the prescription of antibiotics, for example). The first issue was linked to the socalled hygiene hypothesis (Strachan, 1989), according to which children might be brought up an environment that is too clean and therefore have reduced exposure to pathogens that might stimulate the immune system, a context in which some are now advocating probiotics (Murch, 2005). The second issue was linked to failures in the UK health system, including an inability to deal with hygiene, and here too probiotics are being explored as a remedy, especially with relation to Clostridium difficile and antibiotic associated diarrhoea (Hickson et al., 2007). What Fuller called the 'natural inhabitants of the gut' have gradually become enlisted in fighting their nasty 'cousins' - the superbugs - as well as in helping to build up the immune system's natural defences against other illnesses of 'modernity', such as allergies.

An article, again inspired by research at the University of Reading, published in 1987 and entitled 'Innovation: Yoghurt in ferment' (Bird, 1987) is the first to talk about what would become a boom industry in the 1990s, namely the search for a probiotic yoghurt for humans, especially, again, for premature babies whose immunity was compromised. The theme of bugs as 'inhabiting' or as 'living' in our gut is continued.

SCIENTISTS trying to develop healthier yoghurt have found the answer in our stomachs. They are using the bugs that live in the human intestine to ferment milk into a product that actually does you the good which health fanatics claim for yoghurts, mostly without foundation. (Bird, 1987)

The article exploits various dichotomies: between lay knowledge or 'myths' (about yoghurt) and expert knowledge or 'science' (about bacteria); between probiotics and antibiotics; between natural ('the body's natural defences') and artificial or 'inert chemicals whose aim is to kill off the bad bugs but which in 
practice tend to kill beneficial bacteria as well'; and between 'good'/'beneficial' and 'bad'. Here good bacteria are enlisted in the fight against infection - a war scenario that would be used again and again, especially with relation to the emergent theme of 'the vulnerable immune system'. 'By adding a concoction of the bacteria normally found in mothers' milk, doctors could arm premature babies with natural bacterial mechanism to fight infection and develop immunity.' (Bird, 1987) In contrast with the press coverage of 'bad' bacteria and superbugs (see Nerlich and Koteyko, in press), the war metaphor scenario is, however, not dominant, which is not astonishing, as the focus is, as we shall see, on recruiting the help of friendly bacteria to protect, enhance, rebalance and so on - as the late Joshua Lederberg, Nobel prize winner and pioneer in bacterial genetics, would later say, to make 'peace' with bacteria (Lederberg, 2003).

An article published in 1988 (Collings, 1988) switches the debate about probiotics from science to pseudo-science. It is written for the Guardian by Jillie Collings and entitled 'Thursday Women (Life Forces): A new world view'. Collings subsequently published a book entitled Life Forces: Guidelines for a healthy life on a polluted planet (Collings, 1991) whose synopsis on Amazon.co.uk reveals that it is 'A guide to New Age and alternative medicine based on the author's column of the same name in "The Guardian". The author has also written "Astrology and Your Child" and "Around the Next Corner".'

In her article, Collings correctly reports that '[f]irst there were antibiotics and they were considered miraculous. But then resistant strains of bacteria began to develop and we witnessed the growth of a diversity of illnesses which seemed to be untouched by the antibiotics.' One should add that antibiotics can directly cause this 'imbalance' by depleting the gut's normal bacteria. She then goes on to say that the concept of probiotics was introduced by Monica Bryant a follower of the German Professor Günther Enderlein (1872-1968) (who introduced the concept of 'somatic ecology' and began a movement that called itself 'new microbiology'; see Bryant, 1986). Using Bryant's work, Collings expresses, as 
Fuller wrote in a letter to the editor, 'a rather unclear view about what probiotics are' (Fuller, 1988). However, it contains some notions which later blossomed in the more popular understanding of probiotics - which still wavers between the scientific and the 'alternative'. Collings talks about bacteria in the gut as an ecosystem and symbiotic system ${ }^{2}$ that has become imbalanced, something that can lead to inner pollution which can be just as bad as the effects of pollution on the planet. Using insights from Mary Douglas (1966), one might see here an appeal to readers to preserve the 'inner' purity of their bodies and protect them from dangers and pollution lurking in the 'outer' environment, especially from 'bad bacteria', the dirt of the microbial world.

This transfer of concern from the outer to the inner, the macrocosm to the microcosm and from concerns for the 'balance of nature' to the 'balance of the gut' happened at a time when environmental concerns were on the rise. In ecology, the metaphor of 'the balance of nature' is widely used and the idea that there is an inherent equilibrium or balance, with plants and animals interacting so as to produce a stable, continuing system of life on Earth is commonplace together with the view that activities of human beings can, and frequently do, disrupt the balance of nature (see Cuddington, 2001). Two years before Collings published her article, Beck had published his book on the risk society and modernity (Beck, 1986) partly because of rising fears of environmental pollution. In this context probiotics appeared to offer at least one defence against the risks of living in a modern world. For Collings, following Bryant, probiotics held out the hope of restoring the out of balance ecosystem of our gut and of giving people control over their inner world in a context of an outer world that was out of order

$2 \quad$ This type of discourse is now becoming commonplace when popularising recent advances in genomics and microbiology, as demonstrated by the, mostly American, media coverage of the National Institute of Health's announcement of the 'Human Microbiome Project' at the end of 2007. Scientists frequently refer to the microbiome as a 'bacterial ecosystem'. This ecological view of bacteria has also been adopted by producers of probiotic yoghurt drinks, such as Yakult, who ask their costumers to 'Take care of planet you' (see http://www.yakult.co.uk/whatis_watchtv.html) 
-a theme that would become even more important in future years, plagued by food scares, germophobia and fears of bioterrorism.

The theme of balance is clearly highlighted here and friendly bacteria are portrayed as 'inhabiting' people's gut (as Fuller did too). As we shall see later on, these 'inhabitants', their friends, relatives and enemies are portrayed as 'agents' doing various jobs, especially RE-introducing things that have been lost, and generally mediating between an outer (modern, disorderly) environment and the inner environment which they inhabit and keep in good order.

The 80 s end with a short article for the health section of the Guardian by Fuller entitled 'Farming fauna for good flora - Some healthy bacteria, available in pill or liquid form' (Fuller, 1989b) in which he reports how probiotics, especially at that time in form of supplements, are taking off in Japan. They are better than 'chemical antibacterial agents' because 'these are foreign to the body, leave residues, promote resistance, and upset the balance of gut flora. Probiotics reintroduce the bacteria removed by chemotherapy or simply not acquired and re-establish the natural order.' Balance and 'the natural order' are again the dominant theme. The 80 s were a time when probiotics were promoted as replacements of antibiotics by scientists, such as Fuller, and as natural antidotes to modern life by alternative scientists. This uncertain status between a scientifically 'engineered' food additive and a 'natural' product continues to render the use of probiotics ambivalent even today.

The 90s start with an article that set the tone for many more articles to come. It deals with candidiasis, a condition that had also been the focus of Collings's article, but discusses it from the perspective of traditional medicine. Causes are discussed which will re-emerge later when other articles advise people to take probiotics to alleviate all sorts of conditions brought about by 'modernity', especially stress which 'depletes' the immune system (Hodgkinson, 1990). The issue of 'depletion' is important, as probiotics or 'beneficial bacteria' can then be seen as re-introducing something that is lost. 
Two more articles in the 1990 s explore the health benefits of probiotics from a more popular perspective, one asking 'Can you stomach the idea?' (d'Arcy, 1995), one giving advice on migraine. As already pointed out, in terms of metaphors, the metaphors used in the probiotics media coverage are much less spectacular than the metaphors used in the superbug media coverage (Nerlich and Koteyko, in press). The war metaphor scenario is backgrounded, but one can find a number of what one might call 'situated metaphors' which exploit the 'situation' in which bacteria live, namely the yoghurt ('yoghurt in ferment'; 'message in a tub of yoghurt') or the 'situation' into which the bacteria are introduced ('can you stomach the idea'; 'food firms swallow a tough diet of EU laws', etc. $)^{3}$

Three long feature articles were published in the 1990s, one in 1991 for The Times by the science writer and former editor of the New Scientist, Bernard Dixon (who went on to write a book in 1994 entitled Power Unseen: How microbes rule the world), one by Jane Alexander for the Daily Mail in 1994; and finally Mitchell's article for The Times in 1995, which has already been mentioned. Dixon's article (1991) is one of the last ones to focus on probiotics in animals in the context of salmonella outbreaks. He summarises the history of probiotics and goes on to report on Finnish research, which, yet again, establishes a thematic link between probiotics and hygiene (in the sense of the hygiene hypothesis) on the one hand and food poisoning on the other. Whereas chickens hatched in natural conditions pick up bacteria from their mother's faeces which protect them against salmonella infection (something called competitive exclusion), chickens reared in ultra-hygienic conditions do not and might profit from probiotics. This is an issue that is discussed again under the heading of 'biosecurity' in debates about the causes and spread of avian influenza for 'double grounding' metaphors, see Feyaerts and Brône (2002). 
example (see DEFRA, 2007) and in debates about the pros and cons of industrial versus organic poultry farming.

Dixon's book about bacteria (Dixon, 1994) was published at a time when fears about microbes and superbugs began to accelerate and when two popular science books were published that painted a picture of superbugs against the apocalyptic background of plagues and global catastrophe (Garrett, 1994; Cannon, 1995). The term superbug was first used in the mid-1980s, "usually in the context of stories about pesticides and the agricultural use of antibiotics", until in about 1997 superbug became a quasi-synonym for MRSA in the media (Washer and Joffe, 2006: 2145). It now also covers the issue of Clostridium difficile which recently emerged as a new superbug threatening hospital patients who can develop this disease after antibiotic therapy. In this context probiotics are discussed again as protective agents (Hickson et al., 2007). In contrast to Cannon and Garrett, Dixon does not announce a coming apocalypse though. Instead he portrays the many, diverse, entertaining and often unexpected activities of microbes through a series of 75 short stories.

By 1994 journalists also began to write about the hype surrounding probiotics as a panacea for all ills or a cure-all, especially one long article by Jane Alexander written for the Daily Mail in 1994 and entitled "Can a bug really help you become a sleeping beauty?" (Alexander, 1994). Alexander reports that research has shown some benefits but that probiotics cannot, for example, cure cancer. She quotes two experts, who, although acknowledging 'pleasant knock-on effects' of probiotics, also warn about the 'over-hype'. The article introduces a dose of reflexivity into the emergent trend of nutritional or health advice provided by the media where 'experts' urge people to eat, take or buy certain probiotics to alleviate a host of ills. One theme which is highlighted again is the way that probiotic bacteria are personified as families and friends (as opposed to 'armies' of bad bacteria). They are good guys, friends, family members, some even have celebrity status, as we shall see below. 'Naïve' or 'lay' biology based on 
personifying biological entities as agents overlaps here with scientists own conceptualisations of bacteria as friends or enemies, as families and communities (see Wagner, 2007; Nerlich and Koteyko, in press).

As indicated above, the last article of the first probiotic decade, the 1995 article by Mitchell, predicts a tidal wave of products. Mitchell's article for the first time quotes a series of marketing specialists, not scientists, such as John Young, the manager of the functional foods working groups at the Leatherhead Food Research Association, as saying: '

Things are really gathering pace in this area. The opportunities are endless and the interest is huge. I have been in the food industry for at least 20 years and this is the biggest thing yet.' (Mitchell, 1995)

David Whitehouse, the marketing director of MD Foods agrees when he says that until now, health-conscious consumers have found themselves either taking vitamin pills or denying themselves certain ingredients or products. Now, 'the dogood benefits can be incorporated in our normal diet' (ibid.).

This incorporation and 'normalisation' of 'goodness' is therefore a double one; it is incorporated into the food, which then incorporates the goodness into the human body. This process generates (perhaps) health benefits for the buyers of such products, but, more importantly, it generates added financial benefits to those who produce and market them. This marketing potential became the focus of the next probiotic decade.

\section{Recent coverage of probiotics, 1996-2006: between the miraculous and}

\section{the mundane}

In the previous section we have traced the emergence of probiotics as a topic for the media, as promoted by scientists and as debated by journalists. We have also established a list of major themes. Despite warnings about over-hyping probiotics' potential, the hype surrounding probiotics did not decrease noticeably from 1996 onwards. It even increased at the turn of the millennium, despite 
some cautionary advice by scientists such as Jeremy Hamilton-Miller and Glenn Gibson which was quite widely reported (see Yapp, 2004; Wyke, 2005; Gordon, 2005).

In this section we will explore the lexical surroundings of the term 'probiotic/s' (total frequency of occurrence 2063) in our corpus of 837 articles (see Figure 2 below) using collocational lists and concordances in order to survey general trends of coverage in terms of the continuation of old themes and the emergence of new ones.

Whereas in the first ('thematically' oriented) 'probiotic decade' no articles on probiotics appeared in the popular press, the popular press published more articles on probiotics in the second (more 'episodically' oriented) decade than some elite newspapers. It should be noted that The Times clearly leads the field in reporting on this issue, as on health issues in general.

And whereas in the 1980 s long articles by journalists writing for elite newspapers and debating the use of probiotics in animals and humans predominated, from about 1995 onwards short, advice-giving articles on how to use probiotics for various purposes came to dominate the press coverage, both in the elite and popular press. What was once the topic of scientific and popular debate began to be normalised.

For example, we found 50 articles of the 'Dear Doctor' type in Daily Telegraph and 22 articles with advice by Dr Thomas Stuttaford in The Times. A number of other advice-giving articles mentioning probiotics appear in various sections of both popular and elite newspapers and their typical titles include 'Health Zone', 'How to... give yourself a new body shape/ avoid the bugs', or 'Questions and Answers'. In general, the word 'advice' is used 408 times in the corpus.

As the second corpus is too large for a detailed qualitative analysis, we started our analysis by generating a collocational profile for the term 'probiotic' and then proceeded to explore concordances of its most frequent collocates in 
more detail. A quick scan of the 'extended contexts of use' generated by WordSmith (Scott, 1999) for 'probiotic' shows that probiotics are no longer discussed as new or old solutions, and there is hardly any speculation about their future use, advantages or disadvantages - rather probiotics are simply mentioned as an existing 'supplement' which should be taken to relieve certain symptoms. It is these symptoms/health problems that make the theme of these articles, whereas probiotics seem to appear only as an episodic element.

The collocate list of 'probiotic/s' shows that the word is frequently used together with the verbs help (193) and boost (51). The same trend is evident for collocates of the word combinations good/beneficial or friendly bacteria, as the verbs 'help' and 'boost' appear towards the top of their collocational lists organised in the descending order of frequency. The lemma 'probiotic' is also frequently accompanied by the modal verbs can (191) and may (75), and only in 83 cases by a more definitive will, which points to the hedging of claims associated with the benefits of probiotics - a careful framing common for functional food products which lie on the borderline between food and drugs.

The term 'probiotics' stands both for beneficial bacteria and products containing them. An examination of the concordances of 'help' and 'boost' therefore revealed two types of contexts: 1 ) examples where numerous health benefits of beneficial bacteria are detailed and 2) contexts of use where products containing probiotics are said to help to restore or boost/ promote growth of good/beneficial/friendly bacteria. The former are interesting because they enable us to explore the 'behaviour' of friendly bacteria as agents, whereas the latter examples of use may show how entrenched the definition of 'friendly bacteria' has become in in the second probiotics decade.

Probiotics are reported to help the body and the digestive system (see figure 2): the body to combat stress, the gut to break down food and produce natural antibiotics, the digestive system to work more effectively. On a more general level, they 'help the user to cope with hectic lifestyle'. Probiotics also help 
to: rebalance, replenish, rebuild, and restore the good bacteria, redress the balance of good and bad bacteria; they not only 'maintain digestive health' but 'prevent infectious diseases' especially in infants, 'improve thinning hair', 'prevent autism' and so on:

N

1 f food than normal.

$\mathrm{n}$ the digestive tract) holds many probiotic organisms to help maintai

st fluids," says Seki. "And take a probiotic supplement to help put

re than 14 days in total. A probiotic supplement will help to

, drink cranberry juice and take a probiotic supplement to help keep

st fluids," says seki. "And take a probiotic supplement to help put

$t$ one fifth of the population. But probiotic supplements can help red

body of vital healthy bacteria, so probiotic supplements help to resto

tion of good-quality scar tissue. Probiotic supplements will help to Marber advises: "Also take probiotic supplements as these help

ou. The jury is still out but some probiotic supplements and drinks ma

y unhealthy diets and antibiotics. Probiotic supplements help to top

complications such as septicaemia. Probiotic supplements help to reple

Figure 2: Concordance of 'probiotic' with 'help' in extended context

Probiotics are also reported to 'boost' a number of things (see figure 3): from

general health to 'energy levels', 'intestinal health' and the 'immune system':

N

Concordance

1 for children and, for an extra boost, a probiotic

2 E TOWNDAIRY 'S BIO BOOST, 99p for 500ml Probiotic

3 Goive your digestion a boost with with a probiotic

4 additives and colourings. 2 TAKE a probiotic

5 iotics are necessary, give your child a probiotic

6 "You be better off having a daily probiotic

7 fab new flavours to tempt you, including Probiotic

8 e age of 60 should be encouraged to take probiotic

$9 \mathrm{n}$ of nutrients from my meal. Take probiotic

10 bson thinks everyone over 60 should take probiotic

11 ion. Now scientists have discovered that probiotic

12 itute in Sweden which demonstrates that probiotic

13 oving digestion, there is evidence that probiotic

14 c smoothies (recent research shows that probiotic

15 e your well- being. But half of the probiotic

16 e your well- being. However, half of the probiotic

17 OST YOUR MMUNE ;YSTEM Multibionta Probiotic

In the winter months, I alway bacteria: Lactobacillus supplement. Probiotics ar multivitamin in order to boost to help boost the good bacteri drink to boost your digestion

Strawberry Yoghurt, Probiotic products daily to boost their multivitamin supplement. This w products to boost levels of " bacteria may also boost happin yoghurt drinks boost our immun products may boost health in 0 drinks can boost immune system supplements that claim to boos supplements that claim to boos Multivitamin, J 11.25 for

Figure 3: Concordance of 'probiotic' with 'boost' in extended context 
The frequent use of the words 'supplement' and 'supplements' in the corpus (287 occurrences in total, some of which can be seen in figures 2 and 3) indicates that good bacteria taken in the form of powder and capsules to aid specific health problems became as popular as yoghurts (296 occurrences) eaten to 'balance good bacteria in the gut', which points to the increasing trend of using probiotics as 'remedies'. Whereas during the 1985-1995 decade probiotics were mentioned as aids for digestive problems, the emphasis now is on 'miraculous' qualities of probiotic products as they are discussed as a potential cure for all . As can be seen from the above concordances, ills of modern life such as improper diets, stress, lack of energy etc. are said to be particularly susceptible to treatment with probiotics.

Unlike in the previous decade, articles tend to no longer provide a detailed definition of 'good/friendly bacteria'. For example, an article published in a popular newspaper in 2004 suggests 'boosting' 'superbug-fighting good bacteria with a probiotic supplement such as Biocare's Bio-acidophilus' (Mail on Sunday, October 24, 2004). Probiotics are habitually introduced and defined as simply yoghurt/drinks/supplements that may help to restore or boost the growth of 'friendly' or 'good bacteria' in the gut.

The need to 'top up' good bacteria which are supposed to be depleted by hazards of modern living is presented as an unquestionable assumption in some articles, as the examples below seem to suggest (taken from advice columns of The Daily Mail) (see figure 4).

$\mathbf{N}$

7 ntial in the formation of bones and teeth. YOGHURT Eating natural or probiotic yoghurt will help maintain the population of so-called gutfriendly bacteri

\section{$\mathbf{N}$}

11 inerals in low-fat yoghurt promote strong bones and help reduce blood pressure. Eat probiotic types with added beneficial bacteria to keep the gut and immune system he 
59 y disorders. These are often destroyed by unhealthy diets and antibiotics. Probiotic supplements help to top up a person's population of good bacteria. H

Figure 4: Concordance of 'probiotic' with 'top up' in extended context

At the same time, concordances of 'probiotics' also reveal some scepticism about the purported health benefits of these products (Hamilton-Miller, 2001; Foods Standards Agency, 2004); the 'goodness' of probiotics and functional food in general is questioned and the 'add value' step is criticised as a marketing trick (Feinmann, 2003; Milmo, 2005).

Overall, thematic trends that had begun in the 1980s and 1990s continued in the new millennium with a focus on the immune system, balance and the friendly 'inhabitants' of the gut. What is new however is the increase in claims that probiotics 'boost' various aspects of bodily function and 'may' and even 'will' cure or help to alleviate a plethora of ills.

\section{Conclusions}

Comparing the initial coverage of probiotics with the later one, it becomes apparent that probiotics, or 'friendly bacteria', were first framed much more 'thematically' and later much more 'episodically', to use Iyengar's (1991) terminology. The early coverage, mainly by elite newspapers, explored the emergence of probiotics in some depth in the context of larger issues, such as animal husbandry, the rise of antibiotic resistance, care for premature babies, the emergence of hyped-up expectations and so on. In the later coverage, when the popular press began to focus on the issue, probiotics came to be tagged onto more incidental health advice and personal interest stories. Some themes from the early coverage, such as probiotics in animal husbandry, disappeared completely, whereas other themes such as 'balance' and 'bacteria as inhabitants of the gut' increased in popular appeal. 
From being used therapeutically for certain conditions and for certain animals, especially young chicks, probiotics came be seen as beneficial for the entire human population. To bring about this change of perception, scientists, especially Roy Fuller, enlisted the help of the media. They also enlisted probiotic bacteria as agents of change by conceptualising them as friendly inhabitants of the gut and guardians of individual health and wellbeing. The media's portrayal of bacteria as friendly, beneficial helpers of the human body made something that was initially a bit strange and alien familiar and less threatening. In this way the media coverage of probiotics played a crucial role in connecting science, politics and popular consumer culture. It made it possible to imagine bacteria in a new way, as the 'good guys' doing good work inside a part of the body that is not frequently thought about, namely the human gut.

The 'shift to probiotics', predicted and promoted by both scientists, such as Fuller (1985), and alternative medicine practitioners, such as Bryant (1986) in the 1980s, at a time when modern society came to be framed as a 'risk society', has definitely happened. Manufacturers are successfully exploiting this shift and the hopes and fears on which it is based. Individuals are increasingly 'buying into' the promise that probiotics can re-balance a life that seems to be out of balance and establish an inner order in a disorderly and risky outer world. As Devcich et al. (2007) have shown, participants in their study who had higher levels of modern health worries had a greater acceptance of functional foods designed to reduce the likelihood of disease compared to participants with low modern health worries.

The rising popularity of probiotics as all-round remedies can be seen as part of a general trend in 'medicalisation' (Ballard and Elston, 2005; Conrad, 2007), which 'means that problems we encounter in everyday life are reinterpreted as medical ones' (Furedi, 2005). And not only specific problems, 
whole areas of modern life have become medicalised, especially food shopping, cooking and eating:

In supermarkets, especially in middle-class neighbourhoods, buying food has become like conducting a scientific experiment. Individuals spend hours looking at how many carbohydrates there are, whether it's organic, natural, holistic. [...] At a time of moral and existential uncertainty, health has become an important idiom through which to provide guidance to individuals. (Furedi, 2005)

The medicalisation of everyday life goes hand in hand with the individualisation of risk, predicted by Beck, and the increased reference to individual responsibility in healthcare policy (Brown and Crawford, 2003). In this context probiotics have come to be framed as a personal armour that can be worn in the general struggle for health and well-being in the modern risk society and a post-modern society plagued by various types of 'bio-terrorism'. Probiotics can become one way of creating what Szasz has recently called an 'imaginary refuge' in which we feel safe and sealed off from the hazards of the modern world (Szasz, 2007).

\section{Acknowledgements}

We would like to thank Dr Nick Wright and Professor Ronald Carter for their comments on an earlier draft of this paper. The article was written as part of the ESRC project 'Enlisting the help of friendly bacteria: Probiotics and visions of health, nutrition and science in a modern world'. Grant number: RES000222289.

\section{References}


ADAMS, J. (2005). Risk Management: Its not rocket science: Its more complicated. <www.socialaffairsunit.org.uk/blog/archives/000318.php> (accessed 10 July, 2007).

ALEXANDER, J. (1994). 'Can a bug really help you become a sleeping beauty?' The Daily Mail, 11 June.

BALLARD, K. and ELSTON M. A. (2005). 'Medicalisation: A multi-dimensional concept', Social Theory \& Health, Vol. 3, No. 3, pp. 228-241.

BBC News (2006). 'Elderly 'should take probiotics', < http://news.bbc.co.uk/2/hi/health/5253182.stm> (accessed 10 June, 2007). BECH-LARSEN, T. and SCHOLDERER, J. (2007). 'Functional foods in Europe: consumer research, market experiences and regulatory aspects', Trends in Food Science \& Technology, Vol. 18, No. 4, pp. 231-234.

BECK, U. (1986). Risikogesellschaft. Frankfurt a. M.: Suhrkamp.

BECK, U. (1992) Risk Society: Towards a New Modernity. New Delhi: Sage.

BIRD, J. (1987). Innovation: Yoghurt in ferment, The Times 17 May.

BROWN and CRAWFORD, P. (2003). The clinical governance of the soul, Social Science and Medicine, 56, (1), 67-81.

BRYANT, M. (1986). 'The Shift to Probiotics', The Journal of Alternative Medicine, Vol.2, pp. 6-9.

CAMPBELL, H. and FITZGERALD R. (2001). 'Food Scares and GM: Ambivalent Technologies, Fear and The Politics of Nostalgia', Paper delivered to ISA 2001 Conference New nature, new cultures, new technologies, Fitzwilliam College, University of Cambridge, July 2001.

CASEWELL, M., FRIIS, C., MARCO, E., MCMULLIN, P. and PHILLIPS, I. (2003). 'The European ban on growth-promoting antibiotics and emerging consequences for human and animal health; Journal of Antimicrobial Chemotherapy, Vol. 52, pp. $159-161$.

COLLINGS, J. (1988). 'Thursday Women (Life Forces): A new world view', The Guardian xx 
COLLINGS, J. (1991). Life Forces: Guidelines for a Healthy Life on a Polluted Planet. London: Hodder \& Stoughton.

CONRAD, P. (2007). The Medicalisation of Society. Baltimore: John Hopkins University Press.

CRAWFORD, P., BROWN, B., NERLICH, B. and KOTEYKO, N. (in press). 'The moral careers of microbes and the rise of the matrons: An analysis of UK national press coverage of methicillin resistant staphylococcus aureus (MRSA) 1995-2006', Health, Risk \& Society.

CUDDINGTON, K. (2001). 'The 'Balance of Nature' metaphor and equilibrium in population ecology', Biology \& Philosophy, Vol. 16, pp. 463-479.

D'ARCY, S. (1995). 'Can you stomach the idea?', The Sunday Times, 23 April. DEFRA (2007). Avian influenza (Bird flu): Questions \& answers, Department for Environment, Farming and Rural Affairs:

<http://www.defra.gov.uk/animalh/diseases/notifiable/disease/ai/qanda/publicsafety.htm> (accessed 7 September, 2007).

DEVCICH, D, I. PEDERSEN and K. PETRIE. (2007). 'You eat what you are: Modern health worries and the acceptance of natural and synthetic additives in functional foods', Appetite, Vol. 48, No. 3, pp. 333-337.

DIXON, B. (1991). 'The milk's off, but it will do you good; Microbe of the month: Lactobacillus. Bernard Dixon on the yoghurt theory', The Independent, 15 April. Dixon, B. (1994). Power Unseen: How Microbes Rule the World. Oxford: Oxford University Press.

DOUGLAS, L.M (1911). The Bacillus of Long Life. London: TC and EC Jack. DOUGLAS, M. (1966). Purity and Danger: An Analysis of the Concepts of Pollution and Taboo. London: Routledge and Kegan Paul.

DUPRÉ, J. (2007). 'The Friendly Germ Meets the Selfish Gene: Towards a Less Hostile View of Nature', Horning Lecture, The University of Exeter, 5 April. FEINMANN, J. (2003). 'A culture of hype? Probiotic products are all the rage, but do they actually do any good?' The Times, 23 November. 
FEYAERTS, K. and BRONE, G. (2002). 'Humor through "double grounding": structural interaction of optimality principles', Odense Working Papers in Language and Communication, Vol. 23, pp.313-336.

FITZGERALD, R. and CAMPBELL, H. (2001). Food scares and GM: Movement on the nature / culture fault line. Symposium, Food Safety and Security:

<http://www.australianreview.net/digest/2001/10/fitzgerald_campbell.html> (accessed 16 July, 2007).

Food Standards Agency. (2004). Research and Survey Programmes: Annual Report.

FREWER, L.J., HOWARD, C., HEDDERLEY, D., and SHEPHERD, R. (1997), 'Consumer attitudes towards different food-processing technologies used in cheese production: the influence of consumer benefit', Food Quality and Preference, Vol. 8, No.1, pp.1-10.

FULLER, R. (1985). 'Futures: The message in a tub of natural yogurt / Probiotic foods', The Guardian, 28 February.

FULLER, R. (1988). 'Probiotics - how they work'. The Guardian, 17 November. FULLER, R. (1989a). 'Probiotics in man and animals', Journal of Applied Bacteriology, Vol. 66, pp. 365-378.

FULLER, R. (1989b). 'Health Guardian: Farming fauna for good flora - Some healthy bacteria, available in pill or liquid form', The Guardian, 15 March. FUREDI, F. (2005). 'Our unhealthy obsession with sickness'. Spiked-online: <http://www.spiked-online.com/Articles/0000000CA958.htm> GASKELL, G., ALLUM, N., WAGNeR, W., KRONBERGER, N., TORGERSEN, H., HAMPEL, J., and BARDES, J. (2004), 'GM foods and the misperception of risk perception', Risk Analysis, Vol. 24, No.1, pp.185-94.

GASKELL, G., BAUER, M.W., and DURANT, J. (1998), 'Public perceptions of biotechnology in 1996: Eurobarometer 46.1', in Durant, J., Bauer, M.W., Gaskell, 
G. (Eds), Biotechnology in the Public Sphere: A European Sourcebook, Science Museum, London, pp.189-214.

GORDON, B. (2005). 'The 'friendly' bug we all want to catch', The Daily

Telegraph, 8 March.

HAMILTON-MILLER, J. M. T. (2001). 'A review of clinical trials of probiotics in the management of inflammatory bowel disease', Infectious Disease Review Vol. 3, pp. 83-7.

HICKSON, M., D'SOUZA, A. L., MUTHU, N., ROGERS, T. R., WANT, S., RAJKUMAR, C., and BULPITT, C.J. (2007). 'Use of probiotic Lactobacillus preparation to prevent diarrhoea associated with antibiotics: randomised double blind placebo controlled trial', British Medical Journal, 335:80.

HODGKINSON, J. (1990). 'The facts about candida', The Sunday Times, 24 June. HPA (2006). Health Protection Agency: Deliberate Release - Details about the Organism - Botulism. <http://www.hpa.org.uk/ (accessed 16 July, 2007)>. HUNT, S., FREWER, L.J. (2001). 'Impact of BSE on attitudes to GM food', Risk Decision and Policy, Vol. 6, No. 1, pp. 91-103.

ILIFFE, S. (1990). 1980s: a decade of diarrhoea. Health Matters:

<http://www.healthmatters.org.uk/issue5/diarrhoea> (accessed 16 July, 2007). IYENGAR, S. (1987). 'Television news and citizens' explanations of national affairs', American Political Science Review, Vol. 81, pp. 815-831.

IYENGAR, S. (1991). Is Anyone Responsible? How Television Frames Political Issues. Chicago: The University of Chicago Press.

JACOBSEN, E. (2004). Corporate food safety systems - motivations. Project Note no 3-2004. Oslo: National Institute for Consumer Research

KNOTHE, H. (1995). 'The story of live human bacteria administered orally as a remedy'. Infection, Vol. 23, pp. 201-202. 
KNOWLES, T., MOODY, R., and MCEACHERN, M. G. (2007). 'European food scares and their impact on EU food policy', British Food Journal, Vol. 109, No. 1, pp. 4367. KOTEYKO, N. and NERLICH, B. (2007) 'Multimodal discourse of probiotic web advertising', Vol. 23, pp. 20-31..

Lederberg, J. (2003) 'We must find a new inner peace', Milwaukee Journal Sentinel, 27 April.

MILMO, C. (2005). 'Benefits of probiotic drinks: 'Healthy' bugs: hype or science?', The Independent, 7 November.

MARKS, L. A. and KALAITZANDONAKES, N. (2001). 'Mass media communications about agrobiotechnology', The Journal of Agrobiotechnology Management \& Economics Vol. 4, No. 3, pp. 199-208.

MARRIS, C., WYNNE, B., SIMMONS, P., and WELDON, S. (2001). Public Perceptions of Agricultural Biotechnologies in Europe, PABE Final Report. <http://checkbiotech.org/pdf/pubperc.pdf> (accessed 16 July, 2007). METCHNIKOV, E. (1908). The Prolongation of Life: Optimistic Studies. New York: Putnam and Sons.

MILLAR, M, WILKS, M. and COSTELOE, K. (2003). 'Probiotics for preterm infants?', Archives of Disease in Childhood Fetal and Neonatal Edition, Vol. 88, F354.

MITCHELL, A. (1995). 'Where extra health is stirred into the mix; , The Times 9 August.

MURCH, S. H. (2005). 'Probiotics as mainstream allergy therapy?', Archives of Disease in Childhood, Vol. 90, pp. 881-882.

NERLICH, B. and KOTEYKO, N. (in press). 'MRSA - portrait of a superbug: A media drama in three acts' in A. Musolff and J. Zinken (eds), Metaphor and Discourse. Palgrave Macmillan.

PARKER, R. B. (1974). 'Probiotics, the other half of the antibiotic story', Animal Nutrition Health, Vol. 29, pp. 4-8. 
RAMAN, S. (in press). 'When a simple cut might kill? The implications of technological degradation for democracy', Science as Culture.

REDRUELLO, F. (2004). Health Trends Shape Innovation for Dairy Products. Euromonitor International. www.euromonitor.com (Accessed 16 November, 2006).

SCHERZENMEIR, J. and DE VRESE, M. (2001). 'Probiotics, prebiotics, and synbiotics - approaching a definition', American Journal of Clinical Nutrition, Vol. 73 (suppl.), pp. 361-364.

SCOTT, M. 1999. WordSmith Tools 3. Oxford: Oxford University Press.

Select Committee on Science and Technology Written Evidence (2002). House of Lords, Publications:

<http://www.publications.parliament.uk/pa/ld200203/Idselect/ldsctech/23/23w4 6.htm> (accessed 7 September, 2007).

SINCLAIR, J. 1991. Corpus, Concordance, Collocation. Oxford: Oxford University Press.

SHAW, A. (1999). 'What are they doing to our food? Public concerns about food in the UK', Sociological Research Onine, Vol. 4, No. 3.

SHAW, A. (2000). 'Public understandings of food risks: What do the experts know?' Food Science and Technology today, Vol. 14, No.4, pp. 140-143.

SOIL ASSOCIATION (2007). Soil Association Organic Market Report 2007:

<http://www.soilassociation.org/marketreport> (accessed 10 September, 2007). STRACHAN, D. (1989). 'Hay fever, hygiene, and household size', British Medical Journal, 299:1259-1260.

STUBBS, M. (1996). Text and Corpus Analysis: Computer-assisted Studies of Language and Culture. Oxford: Blackwell. 
STUBBS, M. 2006. 'Corpus analysis: the state of the art and three types of unanswered questions' in G. Thompson and S. Hunston (eds.) System and Corpus, pp.15-36. London: Equinox.

SZASZ, A. (2007). Shopping Our Way to Safety: How We Changed from Protecting the Environment to Protecting Ourselves. Minneapolis: University of Minnesota Press.

TEALE, C. J. (2002). 'Antimicrobial resistance and the food chain', Journal of applied Microbiology Symposium Supplement Vol. 92, pp. 85S-89S.

WAGNER, W. (2007). 'Vernacular science knowledge: its role in everyday life communication', Public Understanding of Science, Vol. 16, No.1, pp. 7-22.

WALLER, A. (2005). 'The creation of a new monster: MRSA and MRSI--important emerging veterinary and zoonotic diseases' (Editorial). Veterinary Journal Vol. 169, No.3, pp. 315-6.

WALLIS, P. and NERLICH, B. (2005). 'Disease metaphors in new epidemics: the UK media framing of the 2003 SARS epidemic', Social Science \& Medicine, Vol. 60 , No. 11 , pp. $2629-2639$.

WASHER, P. and JOFFE H. (2006). 'The 'hospital superbug': social representations of MRSA', Social Science and Medicine, Vol. 63, pp. 2141-52.

WRIGHT, A., S. HENSON, B. MOSELEY, and G. KOENEN (et al.) (2003). Functional Foods. Springer Verlag.

WYKE, N. (2005). 'You're being bugged', The Times, 29 October.

YAPP, R. (2004). 'How 'healthy' yoghurt drinks can be useless', The Daily Mail, 26 October. 